\title{
Idea Spinner Using QURANIC Verses in English
}

\author{
Dr. Lubna Almenoar \\ Assistant Professor of English, Department of Humanities and Social Sciences, \\ College of Science and General Studies, AlFaisal University.
}

\section{Introduction}

The review of key content concepts is absolutely necessary for a teacher to confirm students' understanding of the material. Teachers carry out this process of review with students through feedback and assessment strategies. There are many ways or strategies but they all revolve around eliciting responses of several exploratory tasks which will reveal students' depth of understanding of the material. The review of key content concepts has a direct link with higher order thinking skills questioning. The teacher needs to be equipped with the skill for the type of inquiry involving questions on predicting, explaining, summarizing, evaluating, making connections, interpreting, etc. of the material.

The name of the technique, "Idea Spinner", is derived from the thinking process that goes on during the "wait time" for a response. When the teacher elicits an elaborated response through a higher order thinking skills question, the teacher would give the student some "wait time". The student searches his or her mind when undergoing a thought process, organizing ideas and train of thought, and then participating in the discourse pattern of the Question and Response (QAR) relationship process in an attempt to respond correctly.

The full name of the technique, Idea Spinner Using Quranic Verses in English, is an explicit statement informing the literary text chosen for the Critical Reading classroom. In an attempt to develop multicultural practices in the classroom, selected verses of this authentic sacred text which has been translated into the English language are used. This writer makes a rigorous effort in selecting classroom materials or literary texts depicting a diversified socio-cultural variety to expose her students to different global human societies. For example, this writer has used Japanese short stories, Chinese poems, lyrics of Spanish songs, all of which were translated into the English language. The text chosen for this technique was selected Quranic verses in English.

The Quranic verses in English are used in the classroom bringing focus to or looking from the literary and aesthetic angle apart from the religious angle. The use of Quranic verses in English and imagining the images projected in the text would make possible the weaving through of the thematic expression of visualization.Since the images are those projected from the Quranic verses in English, the images brought to focus are everlasting images because the source text that the images originate from is the sacred Quran. The whole Quran is a book from the past for the people of the present and the future. The knowledge of the content in the Quranic verses in English (or in any other language) is information for people to use as guidelines towards a correct and successful way of life.

\section{In this paper, this writer will:}

1. Show how using information technology can assist teachers in the quest of using Quranic verses in English as literary texts or reading material. Some useful websites are in APPENDIX 2.

2. Demonstrate how to use Quranic verses in English. More is done in APPENDIX 3.

3. Show selected verses: Verses 1-29, Surah (57) Al-Hadid(The Iron) (APPENDIX 1)

4. Merge selected verses and technique, Idea Spinner.

5. Show and suggest pedagogical approaches whereby teachers are able to see the classroom application of the Quranic Verses in English

6. Reexamine objectives achieved

7. Highlight this paper's contribution to the thematic expression of teaching and learning process of university education as a service to multiculturalism, diversity and globalism.

\section{CURRENT RESEARCH ON CULTURAL COMPETENCE}

Chisholm (1994) saw the need for teachers to go through a preservice program for the preparation of dealing with increasingly diverse classrooms:

Teacher educators must ask themselves to what degree their teacher preparation programs:
(a) facilitate increased cultural self-awareness,
(b) cultivate appreciation of diversity,
(c) increase cultural competency, and
(d) prepare teachers to work effectively with a variety of students and parents. 
To the extent that education programs achieve these ends, to that extent do they prepare culturally competent teachers.

Preservice multicultural education is a necessity. It is not a matter of individual preference, curricular appendage, or pedagogical whim. Neither should it be merely an added-on course after providing for the necessary knowledge and skills. Multicultural education is not simply an ethnic issue; it is everyone's issue, for teaching is a multicultural experience. The perspective of multicultural education as something good to have in the program, but not essential to effective, responsible teacher preparation is both hazardous to our health as a nation and oblivious to the current classroom reality and our future.

(Chisholm, 1994)

Cakir (2006) discusses the importance of developing culture awareness in the language classroom:

Teacher's task is to make students aware of cultural differences, not pass value judgments on these differences. Students learning a foreign language have to assimilate many new categorizations and codifications if they are to understand and speak the language as its native speakers do.

Therefore, the reasons for familiarizing learners with the cultural components should be to:

- develop the communicative skills,

- understand the linguistic and behavioral patterns both of the target and the native culture at a more conscious level,

- develop intercultural and international understanding,

- adopt a wider perspective in the perception of the reality,

- make teaching sessions more enjoyable to develop an awareness of the potential mistakes that might come up in comprehension, interpretation, and translation and communication.

(Cakir, 2006)

ESL (2012) addresses teachers to be aware of stereotypes and cultural bias in the language classroom:

There are many ESL classroom and cultural sensitivity issues that teachers must address to ensure they are delivering language instruction without prejudice, discrimination, or bias. By understanding the potential problems with cultural sensitivity, teachers can avoid creating an English-centric classroom while increasing their students' language skills.

One of the biggest unintentional biases teachers of ESL students must face is the assumption that when a student does not understand the English language, they must automatically not understand the classroom material being delivered in that language. This myth can lead to high achieving students being deemed lazy, unmotivated, and unintelligent.

In many non-English speaking cultures, students are brought up with more passive behaviors when interacting with adults. An ESL student may be less willing to approach a teacher for extra help or tutoring. This can lead to a cultural bias and assumptions that non-English speaking students are less intelligent than their native English speaking peers.

At the same time, non-English speaking students can quickly absorb cultural biases against English speakers as they witness a more driven, ambitious educational community than they may be accustomed to. This may lead students to be even more reserved, hampering their language skills even further as they refrain from asking for assistance when needed.

A well balanced ESL curriculum will help both students and teachers overcome preconceived notions about different cultures to create a learning environment where all students are valued for their unique heritages.

(ESL, 2012)

\section{MAIN OBJECTIVES OF A CRITICAL READING SESSION}

Saunders et al (1999) revealed four strategies which work and these four strategies are tied with the literary text or reading material used in class. These four points can also be used as a basis or objectives or intended learning outcomes that a teacher would want to achieve at the end of a critical reading session, including the four language skills. Thus, at the end of a critical reading session, a teacher would want students to have exercised and practiced in these areas:

1. Build students' background knowledge.

2. Draw on students' personal experiences.

3. Promote extended discourse through writing and discussion.

4. Assist students in rereading the pivotal portions of the text.

5. Use of four language skills:

(Saunders et al, 1999:4)

- Reading

- Writing

Listening

- Speaking 
Vogt and Echevarria came up with a technique used to enhance language skills through critical reading. The technique is called "Idea Spinner". The highlights of this technique are:

A large poster with four or more compartments, each having a (academic) task command written in it: Predict, Explain, Summarize, Evaluate, Connect. The teacher could use any instrument to apply the effect of the spinning bottle- A stick, ruler, pen, etc. And then the teacher will ask the question based on the literary text that has just been studied before this activity, according to the task command. If the spin stops pointing in the direction of "Explain", the teacher can ask,"What is the main message of the poem?" Teachers can have a variety of intext questions to provide a purpose for reading. Teachers can vary the questions according to the proficiency and ability levels of students.

Question-Answer Relationship (QAR) - This program teaches students strategies for answering questions. It also points out the sources for different kinds of questions. Here are the three types of answers: Right There The answer is located directly in the reading Think and Search The answer is "between the lines." The reader needs to analyze, make inference and/or predict the answer based on the information in the reading. On My Own The answer is "beyond the lines." The reader must base the answer on his/her own experience.

\section{QURANIC LITERATURE LOG OF A RESEARCHER}

(Vogt and Echevarria, 2008)

This particular paper marks the twentieth paper of a well-thought out plan of this writer for a life-long pursuit of a Quranic Literature Log of her own but perhaps not in the same meaning to that used for a student's Literature Log. This writer will start having a folder of her own called Quranic Literature Log where a list of selected Quranic verses in English by various translators to be used as literary texts or reading material are merged with the technique through various sources for teaching in the Language and Literature classroom. Through this log, a series of new research papers will be written and published.

For this study specifically, the entry which relevantly and tentatively informs is as shown in Table 1- Quranic Literature Log:

Table 1- Quranic Literature Log

Quranic Verses: 1- 29 Surah(57 )Al Hadid (The Iron) (APPENDIX 1)

Topic of verses: God's Existence

Source of Text: $w w w . j a n n a h . o r g$

Technique: Idea Spinner

Source of Technique: Vogt, M.E. and Echevarria, J. (2008).99 Ideas and Activities for Teaching English

Language Learners with the SIOP Model . Boston, Mass: Pearson Education.

\section{THE LESSON PLAN}

Technique:Idea Spinner

Text: Verses 1-29, Surah (57) Al-Hadid(The Iron) (APPENDIX 1)

Level:Advanced (undergraduate)

Duration: Two Hours

The following are the main objectives of a Critical Reading session:

Objectives:

1) Build students' background knowledge: Done in bringing focus to the benefit of reflections and discipline because there exists Allah. Students' awareness is raised through the complexity of the quadrant questions.

2) Draw on students' personal experience: Done in groups when responding to one of the quadrant questions on connecting and relating any verse to their own experience.

3) Promote extended discourse through writing and discussion: Done in discussing and working as a group on summary and responses to quadrant questions.

4) Assist students in rereading the pivotal portions of the text: Done in discussions of a set of 10 verses per group. The teacher adds to summary of meaning of verses and responses to quadrant questions during presentation of spokesperson.

5) Use the four skills:

i. Listening: Done in listening to each other's explanation on the meaning of the verses in preparation of a summary. Done in groups of listening to each other's explanation in response to the quadrant question.

ii. Speaking: Done in explaining to each other the meaning of verses in the PreActivity. Done in groups when working on a response to a quadrant question during the Idea spinner Activity. Done in spokesperson's presentation of group'ssummary and also response to the quadrant question.

iii. Reading: Done in reading a set of 10 verses individually or as a group during the Preactivity in preparation of a summary and also during the Idea Spinner activity in working as group responding to the question from a quadrant. 
iv. Writing: Done in writing notes during peer and teacher's explanation of the verses.Done in preparation of a summary in the PreActivity and also during the Idea Spinner Activity when preparing the response to a quadrant question.

The teacher can begin by distributing copies of the English translated version of the Quran by bya group of Muslims who prefer to be anonymous from jannah.org, specifically, verses 1-29 of Surah (57) AlHadid (The Iron) (APPENDIX 1).

The class can be broken up into 3 groups, each group having a set of 10 verses to work with. The Preactivity preceding the Idea Spinner activity or the main activity, has been used and found to be very effective by this writer during her research work for gathering data. The research methodology followed these simple steps of classroom application, observation, assessment and evaluation, and reflection.

The PreActivity is group work, reading and discussing the meaning of the set of verses given. A spokesperson would come up to provide a summary that the group has prepared related to the meaning and message of the set of verses. During the presentation, the teacher would take the opportunity to correct, guide the spokesperson on the right meaning and message of the verses, if necessary. The teacher could also take this opportunity to highlight difficult vocabulary words and provide an explanation for each word. The teacher could add any background information that the teacher may have read on the selected verses in preparation for teaching. At this point, the teacher needs to encourage note-taking for the purpose of understanding and recalling during the Idea Spinner activity, after the three spokespersons' presentation.

The teacher then shows the class a large poster with four quadrants: Explain, Evaluate, Connect, Create. The teacher explains that each group would send one member to twirl a stick, and whichever quadrant the stick stops at, a question of that particular form (Explain, Evaluate, Connect or Create) would be asked about the set of verses belonging to that particular group. Then, the group would work on the response. While they are doing so, a group member from another group would come up and twirl the stick......and work on another question. Then the third and last group would do the same, after which the first group would be the first to present the response. The teacher would add treatment to the response if necessary. Then the first group would send another member to twirl the stick and the group would work on another question. The second group would then come up to give their response.... and so on.

A set of four to five questions could be prepared for each quadrant. The questions could be broad and general so that the teacher can use these questions for all the groups. The questions are written on index cards, with one side written either Explain, Evaluate, Connect or Create and the other side having the question. The questions could be as follows:

\section{Explain:}

1. Choose a verse that shows God's existence. Explain.

2. Which verse is one of God's miracles? Explain.

3. Explain why we must obey God?

4. Which verse talks about the rewards of Believers? Explain

\section{Evaluate:}

1. Evaluate who would rank highest to God.

2. Evaluate the reward system of paradise and hell.

3. Evaluate who the Believers are.

4. Evaluate who the Disbelievers are.

\section{Connect:}

1. Connect your own experience to any one of the verses.

\section{Create:}

1. Create a reward system whereby it would encourage people to do good in real life situation for example, if you were a teacher.

2. Create an issue that would explain the dangers of hypocrisy.

3. Create an issue that would shine the light on "Time is running out".

4. Create an issue that would shine the light on "Ignoring the Obvious Signs".

\section{Conclusion}

Teachers are aware that having a classroom with mixed or differing abilities is a challenging task on the teacher's shoulders. A good teacher rarely follows a textbook step by step as many aspects of teaching and learning need to be taken into consideration. With mixed abilities or all with the same level of ability, a teacher must create opportunities for students to demonstrate each one's level of knowledge and to create opportunities to for students to express the way each one thinks. Differentiation practice in classroom strategy and in 
assessment strategy is always a useful tool for teachers to equip themselves with for more effective teaching and learning.

Where assessment is concerned, evaluation is then called for but still heeding the differentiation approach. The assessments should reflect both social and academic performance. Therefore evaluation of assessment should involve all of the following:

1. Completion of task

2. Ability to understand through listening to teacher and peers

3. Ability to explain or make connections or predict in material and content

4. Ability to demonstrate individuality and creativity

5. Availability and ability to make choices in tasks which consider flexibility for different strengths and needs.

This technique, Idea Spinner, text of 29Quranic verses in English and the suitable activities carried out in the classroom, each plays its own role in a teacher's successful critical reading session. They are an integral part of the whole teaching session. The same set of intended learning outcomes or objectives was achieved at the end of the Quranic Critical Reading session.

\section{References}

[1] Cakir, I. (2006). Developing Culture Awareness in Foreign Language Teaching.Turkish Online Journal of Distance Education. Retrieved from https://tojde.anadolu.edu.tr/tojde23/pdf/article 12.pdfon June 30 2012.

[2] Chisholm, I. M. (1994).Preparing Teachers for Multicultural Classrooms.The Journal of Educational Issues of Minority Students.Retrieved from http://www.edtechpolicy.org/ArchivedWebsites/chisholm.htm on June 30 ${ }^{\text {th }}, 2012$.

[3] ESL (2012).ESL Classroom and Cultural Sensitivity.YourDictionary.Retrieved from http://esl.yourdictionary.com/lessonplans/esl classroom-and-cultural sensitivity.html on June 30 3012.

[4] Saunders, W., O'Brien, G., Lennon, D., \& McLean, J. (1999). Making the transition to English literacy successful: Effective strategies for studying literature with transition students. Educational Practice Reports, Center for Research on Education, Diversity and Excellence, UC Berkeley. Retrieved from http://escholarship.org/uc/item/1574p5t1\#page-4 on June $30^{\text {th }}, 2012$.

Vogt, M.E. and Echevarria, J. (2008).99 Ideas and Activities for Teaching English Language Learners with the SIOP Model . Boston, Mass: Pearson Education.

The Fifty- Seventh Surah, Al-Hadid (The Iron)

\section{APPENDIX 1}

\section{In the name of God, the Gracious, the Compassionate:}

The teacher can explain that the reverence and respect to the Almighty precedes every surah or chapter of the Quran. These words emphasize that the verses that follow are indeed from the Almighty. These words underscore the authenticity of the Quran. The words Gracious and Compassionate are some of attributes of Allah and these words are also two of His ninety-nine names.

1. Whatever is in the heavens and on earth,- let it declare the Praises and Glory of God: for He is the Exalted in Might, the Wise.

2. To Him belongs the dominion of the heavens and the earth: It is He Who gives Life and Death; and He has Power over all things.

3. He is the First and the Last, the Evident and the Hidden: and He has full knowledge of all things.

4. He it is Who created the heavens and the earth in Six Days, and is moreover firmly established on the Throne (of Authority). He knows what enters within the earth and what comes forth out of it, what comes down from heaven and what mounts up to it. And He is with you wheresoever ye may be. And God sees well all that ye do.

5. To Him belongs the dominion of the heavens and the earth: and all affairs are referred back to God.

6. He merges Night into Day, and He merges Day into Night; and He has full knowledge of the secrets of (all) hearts.

7. Believe in God and His apostle, and spend (in charity) out of the (substance) whereof He has made you heirs. For, those of you who believe and spend (in charity),- for them is a great Reward. 
8. What cause have ye why ye should not believe in God?- and the Apostle invites you to believe in your Lord, and has indeed taken your Covenant, if ye are men of Faith.

9. He is the One Who sends to His Servant Manifest Signs, that He may lead you from the depths of Darkness into the Light and verily God is to you most kind and Merciful.

10. And what cause have ye why ye should not spend in the cause of God?- For to God belongs the heritage of the heavens and the earth. Not equal among you are those who spent (freely) and fought, before the Victory, (with those who did so later). Those are higher in rank than those who spent (freely) and fought afterwards. But to all has God promised a goodly (reward). And God is well acquainted with all that ye do.

11. Who is he that will Loan to God a beautiful loan? for (God) will increase it manifold to his credit, and he will have (besides) a liberal Reward.

12. One Day shalt thou see the believing men and the believing women- how their Light runs forward before them and by their right hands: (their greeting will be): "Good News for you this Day! Gardens beneath which flow rivers! to dwell therein for aye! This is indeed the highest Achievement!"

13 One Day will the Hypocrites- men and women - say to the Believers: "Wait for us! Let us borrow (a Light) from your Light!" It will be said: "Turn ye back to your rear! then seek a Light (where ye can)!" So a wall will be put up between them, with a gate therein. Within it will be Mercy throughout, and without it, all alongside, will be (Wrath and) Punishment!

14. (Those without) will call out, "Were we not with you?" (The others) will reply, "True! but ye led yourselves into temptation; ye looked forward (to our ruin); ye doubted (God's Promise); and (your false) desires deceived you; until there issued the Command of God. And the Deceiver deceived you in respect of God.

15. "This Day shall no ransom be accepted of you, nor of those who rejected God." Your abode is the Fire: that is the proper place to claim you: and an evil refuge it is!"

16. Has not the Time arrived for the Believers that their hearts in all humility should engage in the remembrance of God and of the Truth which has been revealed (to them), and that they should not become like those to whom was given Revelation aforetime, but long ages passed over them and their hearts grew hard? For many among them are rebellious transgressors.

17. Know ye (all) that God giveth life to the earth after its death! already have We shown the Signs plainly to you, that ye may learn wisdom.

18. For those who give in Charity, men and women, and loan to God a Beautiful Loan, it shall be increased manifold (to their credit), and they shall have (besides) a liberal reward.

19. And those who believe in God and His apostles- they are the Sincere (lovers of Truth), and the witnesses (who testify), in the eyes of their Lord: They shall have their Reward and their Light. But those who reject God and deny Our Signs,- they are the Companions of Hell-Fire.

20. Know ye (all), that the life of this world is but play and amusement, pomp and mutual boasting and multiplying, (in rivalry) among yourselves, riches and children. Here is a similitude: How rain and the growth which it brings forth, delight (the hearts of) the tillers; soon it withers; thou wilt see it grow yellow; then it becomes dry and crumbles away. But in the Hereafter is a Penalty severe (for the devotees of wrong). And Forgiveness from God and (His) Good Pleasure (for the devotees of God). And what is the life of this world, but goods and chattels of deception?

21. Be ye foremost (in seeking) Forgiveness from your Lord, and a Garden (of Bliss), the width whereof is as the width of heaven and earth, prepared for those who believe in God and His apostles: that is the Grace of God, which He bestows on whom He pleases: and God is the Lord of Grace abounding.

22. No misfortune can happen on earth or in your souls but is recorded in a decree before We bring it into existence: That is truly easy for God: 
23. In order that ye may not despair over matters that pass you by, nor exult over favours bestowed upon you. For God loveth not any vainglorious boaster,-

24. Such persons as are covetous and commend covetousness to men. And if any turn back (from God's Way), verily God is Free of all Needs, Worthy of all Praise.

25. We sent aforetime our apostles with Clear Signs and sent down with them the Book and the Balance (of Right and Wrong), that men may stand forth in justice; and We sent down Iron, in which is (material for) mighty war, as well as many benefits for mankind, that God may test who it is that will help, Unseen, Him and His apostles: For God is Full of Strength, Exalted in Might (and able to enforce His Will).

26. And We sent Noah and Abraham, and established in their line Prophethood and Revelation: and some of them were on right guidance. But many of them became rebellious transgressors.

27. Then, in their wake, We followed them up with (others of) Our apostles: We sent after them Jesus the son of Mary, and bestowed on him the Gospel; and We ordained in the hearts of those who followed him Compassion and Mercy. But the Monasticism which they invented for themselves, We did not prescribe for them: (We commanded) only the seeking for the Good Pleasure of God; but that they did not foster as they should have done. Yet we bestowed, on those among them who believed, their (due) reward, but many of them are rebellious transgressors.

28. O ye that believe! Fear God, and believe in His Apostle, and He will bestow on you a double portion of His Mercy: He will provide for you a Light by which ye shall walk (straight in your path), and He will forgive you (your past): for God is Oft-Forgiving, Most Merciful.

29. That the People of the Book may know that they have no power whatever over the Grace of God, that (His) Grace is (entirely) in His Hand, to bestow it on whomsoever He wills. For God is the Lord of Grace abounding.

\section{USING INFORMATION TECHNOLOGY USEFUL WEBSITES:}

1. English Index Categorization Alphabetical List of Topics in the Quran: Retrieved from http://www.quranictopics.com/p3ch1-e.html on June 30th, 2012.

2. The English Translation of The Holy Quran Online: Retrieved from http://jannah.org/quran/ on June $30^{\text {th }}$, 2012.

3. Islamicity.com-The Holy Quran. The translations are available in multiple languages. Retrieved from http://www.islamicity.com/mosque/quran/ on June $30^{\text {th }}, 2012$.

4. The way each verse is dealt with by each translator or group of translators is so thorough. After the translation of each verse, a thorough endnote presentation capturing the essence of the surah is laid out. This website is especially useful for researchers and students in the field of translations and comparative literary studies. $\quad$ Retrieved from http://www.quranix.net/\#?RTQ=1\&TMG=1\&MA=1\&RK=1\&SH=1\&TE=1\&A=1\&L=en\&NA=10\&S=1 on June $30^{\text {th }}, 2012$.

5. A linguistic resource showing the theoretical aspects of linguistics: Arabic grammar, semantics, pragmatics, lexicology, phonology, morphology and syntax of each word in the Quran, the descriptive aspects of linguistics: comparative linguistics, etymology, phonetics and sociolinguistics of words and phrases in the Quran, and the applied linguistics aspects: language and vocabulary development, psycholinguistics and stylistics of the words and phrases in the Quran. At the end of each surah, there is an audio Quran recitation of the surah by the recitor, SaadAlGhamadi. Retrieved from http://corpus.quran.com/wordbyword.jsp on June $30^{\text {th }}, 2012$.

6. Teachers can also download Islamic songs on CDs for classroom use. It comes with lyrics of each song, a list of artists and their songs. Retrieved from http://www.islamiclyrics.net/on June 30 ${ }^{\text {th }}, 2012$. 


\section{APPENDIX 3 \\ CLASSROOM APPLICATION OF QURANIC VERSES IN ENGLISH}

Quranic Verses in English: Teaching Imagery:

In the case of Descriptive imagery, an illustrated example is from Abdullah Yusuf Ali's English Translations of the Quran, Verse 29 of Surah(18) Al-Kahf:

\section{Surah (18) Al-Kahf}

Verse 29, line 9: That will scald their faces

What type of imagery? Descriptive imagery.

The image gives a vivid description of what the "water like melted brass" can do.

Senses: visual, tactile.

Not only can one imagine feeling the pain of being scalded but one can also picture the disfigurement that the scalding will cause to the faces of the sinners.

In the case of Figurative imagery using the literary device, simile, an illustrated example is from Abdullah Yusuf Ali's English Translations of the Quran, Verse 65 of Surah(37) As-Saffat:

\section{$\operatorname{Surah}(37)$ As-Saffat}

Verse 65, lines 1-3: $\quad$ The shoots of its fruit-stalks Are like the heads of devils

What type of imagery? Figurative Imagery using the literary device: simile.

The word "like" tells one that a simile is being used to compare the shoots to devils' heads.

Senses: visual.

This image gives a vivid picture in our minds of how evil-looking fruits of this tree in Hell are.

In the case of Figurative imagery, using the literary device, metaphor, an illustrated example is from Abdullah Yusuf Ali's English Translations of the Quran, Verse 50 of Surah(38) Sad:

Surah (38)Sad

Verse 50, lines 2 and 3: Whose doors will (ever) Be open for them

What type of imagery? Figurative imagery using a literary device: metaphor.

These doors to the beautiful gardens are forever open to the righteous. Normally, when one thinks of doors, they can either be open or closed. But these doors in Heaven will forever be open. The image metaphorically compares the entrance or passage into Heaven, which we cannot truly visualize, to "doors" in which case Heaven is compared to a gracious house or one's eternal home. The image of open doors depicts Heaven as an abode that feels familiar, hospitable, welcoming.

Senses: visual.

The image suggests a mental picture.

In the case of Figurative imagery using the literary device, symbol, an illustrated example is from Abdullah Yusuf Ali's English Translations of the Quran, Verse of Surah(15) Muhammad:

\section{Surah (47) Muhammad}

Verse 15, lines 6-8: $\quad$ Rivers of milk

Of which the taste

Never changes

What type of imagery? Figurative imagery using a literary device: symbol.

Again, unlike the earthly milk which can turn sour without refrigeration, this "milk" in Heaven tastes forever fresh. This "milk" can be found in the form of rivers-- in abundance.

Sense: visual, gustatory, tactile, olfactory.

This image makes one imagine whether this "milk" looks like that consumed on earth; how delicious it must taste, and cool it must feel, and fresh it must smell. 


\section{QURANIC VERSES IN ENGLISH: STYLISTICS APPLICATION}

An illustrated example of a stylistics analysis of Quranic verses in English by translated by Muhammad Asad is Verses 16-18 of Surah(77) Al-Mursalat: (16) Did we not destroy [so many of] those [sinners] of olden days? (17)And We shall let them be followed by those of later times: (18) [for] thus do We deal with such as are lost in sin.

Analysis: Verses sixteen to eighteen are put together to form one paragraph. These verses explain the punishment that awaits sinners in the Day of Judgement-destruction. Verse sixteen questions and verses seventeen and eighteen answers verse sixteen. Verse seventeen begins with the conjunction "And" and is in the future tense and verse eighteen begins with the conjunction [for] followed by "thus" and is in the present tense. Verse seventeen implies that suffering in the hereafter is bound to befall the sinners of later times even if God wills to spare them in this world. "We" is used to refer to God in these verses. These verses show the timelessness, universality and unchanging laws of God - for the past, present and future - sinners are destroyed.

An illustrated example of a stylistics analysis of Quranic verses in English by Abdullah Yusuf Ali is Verse 27 of Surah (77) Al-Mursalat:

27. And made therein Mountains standing firm Lofty (in stature); And provided for you

\section{Water sweet (and wholesome)?}

Analysis: Verse twenty-seven tells one of Allah's creative activity and hence, His existence when it is evident that mountains-hard and solid, high in altitude - are able to distribute or provide man with pure delicious, sweet water in the form of rivers and springs. The conjunction "and" is used twice in lines one and four. The metaphor is describing the mountains as "standing firm, lofty (in stature)" suggests that these mountains are hard, solid and tall or high in altitude. The word, "wholesome", suggests pure and untouched by man. If the wisdom and power of Allah can do so much before our eyes, we therefore, cannot reject His teaching of a still more wonderful future life after death. Verses twenty-five to twenty-seven are in the past tense. 